\title{
RESEARCH INTO ADVERTISING IN CONSTRUCTION: ANALYSIS OF LITHUANIAN AND SWEDISH EXPERIENCE
}

\author{
Audrius Banaitis ${ }^{1}$, Nerija Banaitien $\dot{e}^{2}$ \\ Department of Construction Economics and Property Management, \\ Vilnius Gediminas Technical University, Saulètekio al. 11, LT-10223 Vilnius-40, Lithuania \\ E-mail:1'Audrius.Banaitis@st.vtu.lt; ${ }^{2}$ Nerija.Kvederyte@st.vtu.lt
}

Received 16 September 2005; accepted 5 December 2005

\begin{abstract}
Construction, as an object of marketing, has special features: the construction environment is complex and changing, clients' requirements and expectations are increasing. Construction companies must realize that good marketing, as well as advertising activities have a great impact on sales of construction products and services in today's competitive market. This paper reports on a qualitative study of the Lithuanian and Swedish construction companies about advertising campaign, budget and means of advertising. The effectiveness of advertising means is also analyzed. The first problem identified in the study is that most Lithuanian construction companies provide self-advertising policy. The lack of experience and knowledge of advertising leads organizations to inadequate decisions. The observations also detected that advertising campaign in the Lithuanian construction companies is underfinanced and the advertising budget is closely linked with used means. The paper concludes with the assessment of the study results and directions for further research.
\end{abstract}

Keywords: Advertising, construction company, advertising means, advertising campaign, survey.

\section{Introduction}

Advertising by traditional and new media continues to contribute to marketing activities of most products and services. In 2004, overall advertising expenditures in Lithuania reached 334.88 million Litas, an increase of $27.9 \%$ from 2003. Compared with 2003 spending on advertising in TV surged $33.9 \%$, newspapers $-25 \%$, magazines $-15.2 \%$, radio $-31.6 \%$ in 2004 . Outdoor advertising market grew $23.5 \%$ in 2004 . The growth of the Internet advertising has worked out $24.3 \%$ and cinema advertising market has sprouted twice [1]. However, many small and medium-sized construction companies invest little or no money in promotion, advertising, market research, new product development or other marketing activities.

The definition of marketing is broad and varying. However, modern marketing is more than just developing of right products and services, pricing them attractively and making them available to customers. Companies must also com- municate with their customers. To communicate well, companies often hire advertising agencies to develop effective advertisements, sales-promotions specialists to design sales incentive programs, and public relations firms to develop corporate images [2]. For most companies the question is not whether to communicate, but how much to spend and in what ways. All of their communication efforts must be blended into a consistent and coordinated marketing-communication program.

A company's total marketing-communication program called its promotion mix - consists of the specific blend of advertising, sales promotion, public relations, and personal selling that the company uses to pursue its advertising and marketing objectives [2-4]. Advertising, promotion, public relations, and sales managers coordinate the market research, marketing strategy, sales, advertising, promotion, prising, product development, and public relations activities. Promotion is used to provide information to various groups of 
customers, to create a positive image of organization. Thus, it has a great impact on sales and share market of organization $[5,6]$. Price is the only element in the marketing mix that produces revenue; the other elements (product, place/ distribution, and promotion) produce costs. Every industry and every company chooses a unique promotional mix, depending on its objectives, capabilities, and markets [7].

Construction, as an object of marketing, has special features: the construction environment is complex and changing, clients' requirements and expectations are increasing. The activities of construction companies are entirely dependent on the prosperity of the other industries who initiate the need for projects to be performed, and where the funding is coming from [8]. The construction companies must realize that good marketing, as well as advertising activities have a great impact on sales of construction products and services in today's competitive market.

The current state of the Lithuanian construction companies is complicated. Cutthroat competition, changes in the political, legal and economic environment, other changes, as well as the growth of globalisation influence construction companies and construction industry in general. Only a few Lithuanian construction companies manage to compete with foreign competitors. Little attention is paid to understanding of client's needs and expectations and analysis of industrial environment and competition which are fundamental elements of strategic marketing. Marketing strategy is common sense, but many companies do not realise its true worth until it is too late to change, and by then the competition has gained their position in the market [8].

The purpose of this paper is to present the analysis of perceptions, attitudes and use of advertising by companies. In particular, it is an examination of the advertising principles in construction companies. Using qualitative questionnaire, this paper reports data from the Lithuanian and Swedish construction companies about advertising, the status of the field and the future aspirations. The aim is to compare advertising in the two countries in order to add to the debate on the campaign, budget and means of advertising.

The rest of the paper is organized as follows: Section 2 provides a review of some relevant literature on advertising. This literature is utilized to review advertising concepts, determination methods of advertising budget, advertising means and strategies, and to identify appropriate research issues. Section 3 introduces a qualitative study that was conducted to address the research issues. Thus, the main part of the paper, presented in Section 3, is composed of the research objectives and tasks, and the report of questionnaire survey. Furthermore, the analysis and results of the conducted survey are presented in Section 4. Conclusion remarks are given in Section 5.

\section{Literature review}

The task of promotion is to insure that targeted consumers know and like the company's products. Perhaps the most obvious form of promotion, advertising is defined as "any paid form of non-personal presentation and promotion of ideas, goods or services by an identified sponsor" [3] and related, "structured and composed non-personal communication of information, usually paid for and usually persuasive in nature, about products (goods and services) or ideas by identified sponsors through various media" [9]. The main goal of advertising is - to persuade consumers to purchase a product or service - the media environment into which advertising is placed is changing, and because of this trend, the nature of advertising is changing as well [9]. Traditional media, such as newspapers, magazines, direct mail, radio, television, and billboards are used to convey an advertising campaign message to the customer. New media, such as email, the Internet, the World Wide Web, and other new technologies create new opportunities for marketing communication [10-14]. As Bezjian-Avery et al. [15] found in a study, the traditional advertising format of conventional advertisements is actually better than interactive advertising for certain kinds of consumers and for certain kinds of advertisements. Advertisers and marketers frequently use multiple communication tools (e.g., advertising, public relations, and personal selling) or channels (e.g., magazines, television, and the Web) [16]. The ultimate goal of employing multiple means is to have them synergize to create the greatest persuasion effect.

A relevant advertising media selection is a strategic factor for construction business. The effectiveness of advertising is a function of its content (the message), execution (how the advertising conveys the message), and frequency (how often a consumer sees the advertising) [3]. The advertising spending level enters the picture only in service of these three factors. If a company does not spend enough on advertising, then its content might be off base, or the advertisements might be poorly executed, or the frequency might be inadequate [17]. The types of media and the frequency of advertisements determine the allocation of the advertising budget.

The volume of sales depends upon consumers' reservation price (or, equivalently, willingness to pay for the product), and the company may invest in an advertising campaign in order to increase consumers' reservation price [18]. One of the hardest marketing decisions facing a company is how much to spend on advertising. Advertising may cost a lot of money but that cost is justified if it works effectively and economically. A good advertising campaign is one, which is planned and conducted so that it achieves the desired results within an acceptable budget [19]. How does a company decide on its advertising budget? Four common 
methods used to set the total budget for advertising: the affordable method, the percentage-of-sales method, the competitive-parity method, and the objective-and-task method [2]. Dalrymple and Parsons [20] propose to use also the experimentation and testing approach, and the modeling and simulation approach. Selection among these methods depends on the extent to which returns form advertising can be identified.

The media planning includes the selection of advertising media, as well as the development and allocation of the advertising budget. The multiple criteria decision-making (MCDM) models also are available to solve media selection and budget allocation problems. Kwak et al. [21] proposed the MCDM model that is able to enhance decision making process and planning policy in media planning.

Advertising that provides information on search or experience characteristics is likely to have different implications on market structure, evolution, and performance than advertising, which creates prestige or image associations that, gives direct utility to consumers [22]. As pointed out by Morrill [23] advertising campaign can change buyer's opinions and attitudes. These changes depend on the frequency and the content of the advertisements. The types of media and the frequency of advertisements determine the allocation of the budget. Each organization must decide how they allocate their advertising funds depending on their goals; each organization will want to see a return on investment.

The ability of an organization to measure the effectiveness of its advertising is crucial to developing advertisements that are more efficient, determining the optimal level of expenditures, and allocating available funds to media. The four most commonly used measures of advertising effectiveness are changes in sales, number of inquiries received, increases in knowledge of the product, and attitude changes. Although the intermediate measures of effectiveness can provide helpful insights, sales are the best criterion for evaluating advertising results [20]. Effective measurement gives an organization the assurance that they are maximizing their investment and provides evidence that the chosen strategy produces the right results.

While advertising is an important component of any marketing strategy, it is important to ensure that advertising is done effectively. Effective communication in advertising requires that specified messages (attributes) be conveyed to potential customers and that the result will be a corresponding demand from these customers at a profitable price [24]. However, without advertising, the products or services cannot flow to the distributors or sellers and to the consumers or users. The feedback from advertising in terms of sales is usually quite slow [25].

Different organizations handle advertising in different ways. In small companies, advertising might be handled by someone in the sales department. Large companies set up advertising departments whose job is to set the advertising budget, work with the advertising agency, and handle direct-mail advertising, dealer displays, and other advertising not done by the agency $[2,26]$. Most companies use outside advertising agencies because they put overall promotional and advertising strategy. Advertising strategy plays an important role in the formation of company's image.

Company's image - i.e. the externally produced symbols and interpretations made by outsiders about the company - exerts a direct influence over its external stakeholders such as clients, suppliers, shareholders etc. However, it also indirectly influences internal stakeholders, particularly the employees, through their perception of how outsiders/ consumers view the company [22, 27]. Information used to determine a company's image may come from sources such as advertising, direct interaction with the company, product or service use, rumours, news reports, or unofficial statements by employees [28]. Many consumers assign some level of prestige to the mass media used in advertising. The simple fact that product is advertised nationally can add to its image [29]. An advertising campaign affects a company's image. Many organisations use institutional or prestige advertising, which is designed to build up their reputation rather to sell particular products [30,31]. Positive image enhances company's success in a variety of ways. If a company's image improves, it sales may also improve due to higher customer loyalty, a greater propensity for the public to believe the company's advertising, and greater public acceptance of the company's brands. Building a strong brand in the market is the current goal of many organizations [32].

\section{The research study}

\subsection{Research aim, objectives and tasks}

This study aimed to investigate how the campaign, budget, and means of advertising of the Lithuanian and Swedish construction companies differ. More precisely, the research objectives were to:

- Explore the campaign, budget and means of advertising in construction companies; and

- Develop recommendations for the advertising strategy in construction companies.

The defined objectives were achieved thorough the accomplishment of the following tasks:

- A thorough literature review, including advertising, marketing and marketing information research.

- Development of a comprehensive structured questionnaire with interviews. The design of the questionnaire was approved by selected experts.

- A questionnaire survey in Lithuania. The survey was drafted in Lithuanian and then translated into English. 
- A questionnaire survey in Sweden.

- Analysis of questionnaires: An analysis was performed to examine the findings. Furthermore, graphics was used to represent the results.

- Generation of conclusions with highlight specific problems and recommendations for advertising strategy in construction companies.

\subsection{Questionnaire survey}

A thorough literature review revealed notable dearth of construction industry marketing, promotion and advertising studies. To address this deficiency the advertising experience of various organization types (such as, project managers, contractors, trading companies, etc.) was examined using a questionnaire survey.

A questionnaire survey was carried out to uncover the status of advertising in the Lithuanian and Swedish construction companies. The aim was to compare advertising in the two countries in order to add to the debate on the campaign, budget, and means of advertising. This was preceded by pilot study in which participants were asked to consider the complexity, intelligibility and length of the questionnaire. The comments received from this pilot study focused on the intelligibility of the questions and the length of the questionnaire and modifications were incorporated into the final version of the questionnaire.

A total of 70 questionnaires was distributed and 30 (41.4\%) completed questionnaires were received, and 25 ( $35.7 \%$ ) were returned duly completed. About $70 \%$ of questionnaires was electronically delivered to the respondents by e-mail and $30 \%$ was delivered directly to the respondents. Of the total respondents $20(80 \%)$ were the Lithuanian construction companies and $5(20 \%)$ were the Swedish construction companies. Various professional occupations were represented including civil engineers, project managers, managers, accountants and traders.

Several categories of questions were included in the questionnaire: (1) About company - activity, practice, company size (number of employees and annual turnover), and market volume; (2) Current marketing/advertising practices - How many people in the company work in the range of advertisement? How much resource did the company assign for advertising last year? What percentage of resources does a company distribute for advertising in different seasons? What method does a company use planning annual budget for advertising? What kind of advertising does the company use? What kind of printed advertising does the company use? What kind of broadcast advertising does the company use? What kind of direct advertising does the company use? What kind of public advertising does the company use? On what does the company's choice of any type of advertising depend? What kind of method does the company use for advertising organization? (3) Attitudes towards advertising measures - How does the company estimate the effectiveness of advertising campaign? How does the company estimate advertising effectiveness per last year? How does the company estimate advertising campaign of other construction enterprises?

\section{Analysis and findings}

Survey respondents were classified into micro, small, medium-sized and large organizations. Figs 1 and 2 provide details about the sample distribution in terms of the enterprise's number of employees and turnover. In 25 organizations $12 \%$ employed fewer than 10 employees, $28 \%$ employed fewer than 50 employees and $36 \%$ employed fewer than 250 employees, and $84 \%$ had annual turnover not exceeding 40 million EURO. Thus, most of the sample was comprised of medium-sized, small and micro-organizations.

Fig 3 provides a summary of organizational funds to advertising as a percentage of company turnover of the Lithuanian construction companies. The results indicate that joint-stock companies invested $1.6 \%$ of their turnover, public enterprises and stock companies invested less than $1 \%$ (accordingly $0.1 \%$ and $0.4 \%$ ). Thus, the joint-stock companies are the most self-advertising enterprises. Most of the construction companies in Lithuania are exactly these enterprises, therefore the main competition is namely among them.

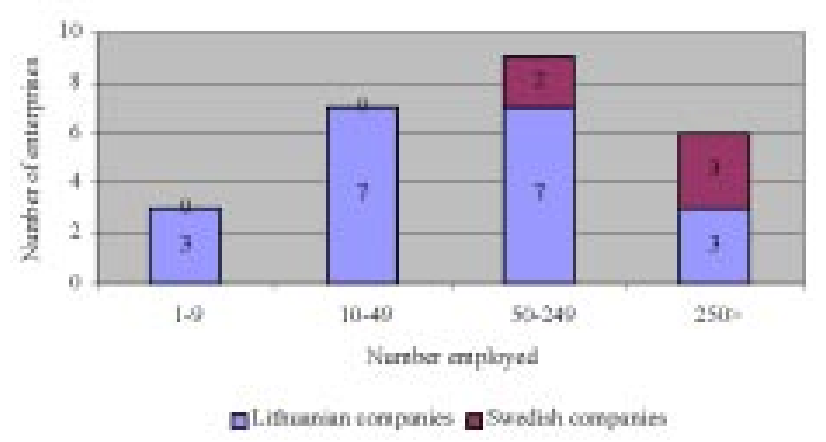

Fig 1. Enterprise size by the number of employees

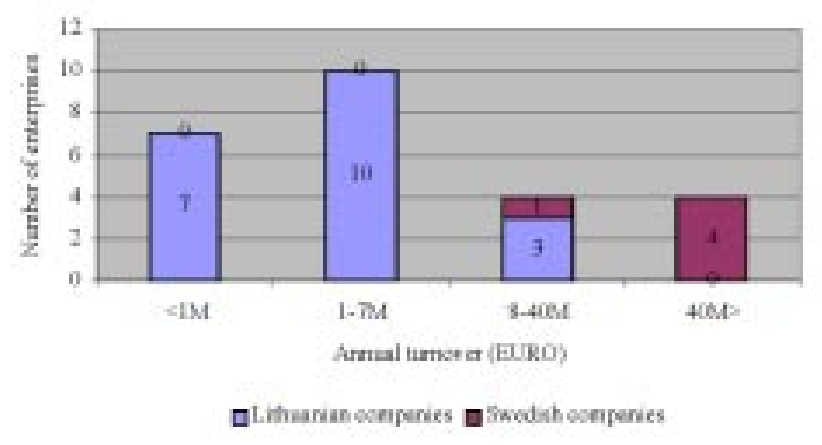

Fig 2. Turnover of sampled enterprises 


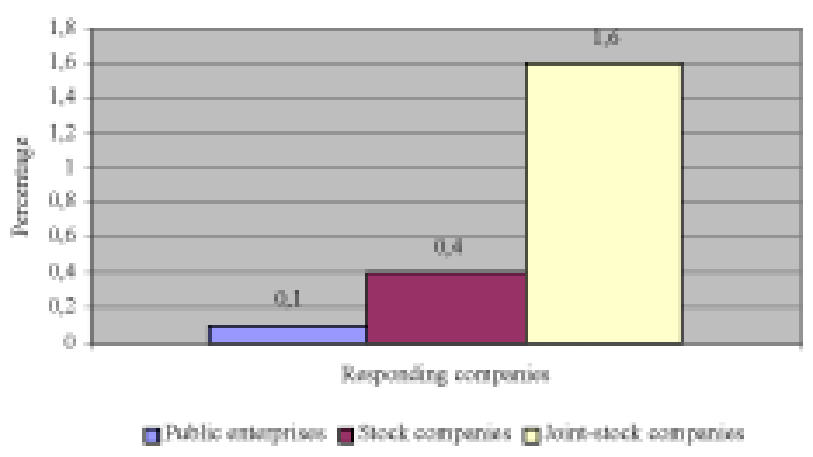

Fig 3. Organizational funds to advertising as a percentage of turnover

One of the hardest marketing decisions facing a company is how much to spend on advertising. Preparing advertising budget, the decisions are made on the overall amount of resources and their allocation.

Advertising media used by construction companies are considerably miscellaneous and variable. Due to complex and unforeseen processes the intensity of advertising campaigns for construction changes constantly. Construction is very sensitive to seasons. The following issues make advertising campaigns of construction companies dependent on seasons: features of occupied market, the type of products and services, an advertising campaign of a company, geographic location, etc.

Fig 4 indicates that the Lithuanian construction companies allocate the biggest part of annual advertising budget, i.e. $27.4 \%$ in spring; $27.2 \%$ in autumn, $23.8 \%$ in summer and $21.6 \%$ in winter. In conclusion, it may be claimed that when companies are preparing for the season in spring they try to inform the clients and public about themselves to the biggest possible extent. Therefore the intensity of advertising increases and in summer, when the sufficient amount of projects/orders is received, the intensity decreases. In autumn when the season is ending and competition increases, companies intensify an advertising campaign once again; and when the season is over advertising is reduced to the minimum in order to accumulate funds for spring advertising campaign.

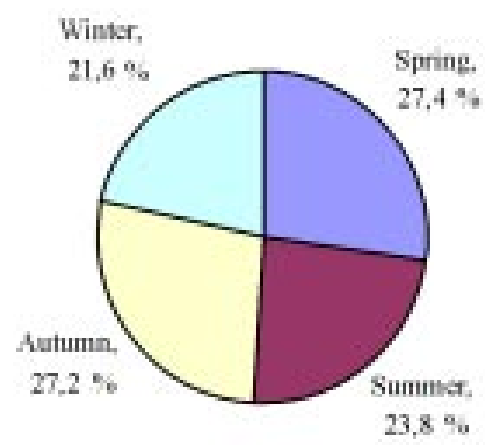

Fig 4. Evaluation of dependence on seasons (percentage of annual advertising budget)

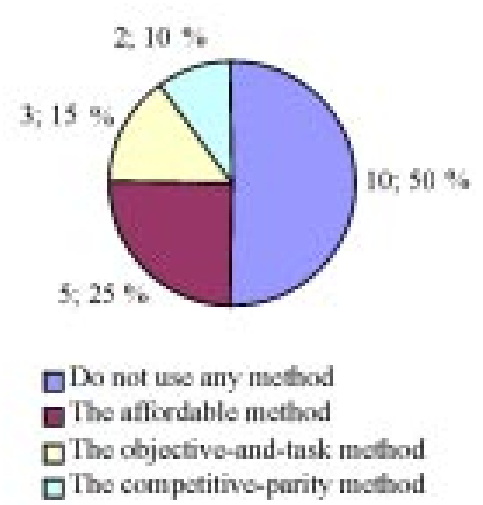

Fig 5. Methods used by the Lithuanian construction companies to set annual budget for advertising

Fig 5 provides a breakdown of the methods used by the Lithuanian construction companies to set the annual budget for advertising. Actually, $50 \%$ of the companies does not use any method for advertising budget decisions, and the percentage-of-sales method is not used. Planning the annual advertising budget five Lithuanian companies, corresponding $25 \%$ of the respondents, usually use the affordable method. The method is based on existing fi-nancial resources of a company. Whereas the profit of the Lithuanian construction companies is relatively very moderate, the application of the method is a beneficent alternative. It has also been noticed that larger and more known construction companies applied this method. As most of the analysed Lithuanian companies are small, medium-sized, and only little profitable, they apply their own principles for planning of advertising budget. Inter-estingly, all Swedish construction companies apply per-centage-of-sales method for planning their advertising budget. It has also been noted that some Swedish compa-nies, planning the advertising budget, apply even several methods.

The intensity of advertising campaign in a construc-tion company depends upon the tasks of the company. Solving these tasks, the first problem is how to select one or several types of advertising media, which could pro-vide the required size of auditorium, sufficient frequency of an advertisement and the required level of its effect in the best possible way using the existing advertising budget.

The determination of the exact advertising budget is one of the most serious stages in advertising planning. While compiling advertising budget, the total amount is determined and the funds are allocated.

Fig 6 indicates that the total advertising budget of eleven Lithuanian construction companies, corresponding $55 \%$ of the respondents, and three Swedish construction companies, corresponding $60 \%$ of the respondents, will remain unchanged in 2005. In addition, six Lithuanian companies, corresponding $30 \%$ of the respondents, and one Swedish 


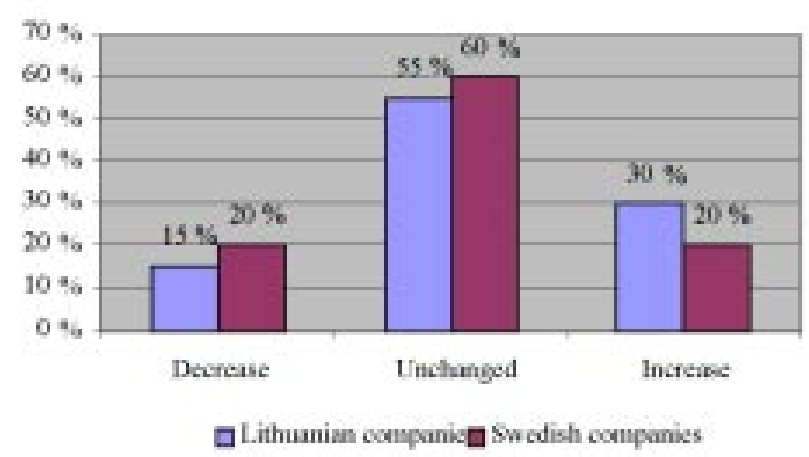

Fig 6. The change of the advertising budget of construction companies in 2005

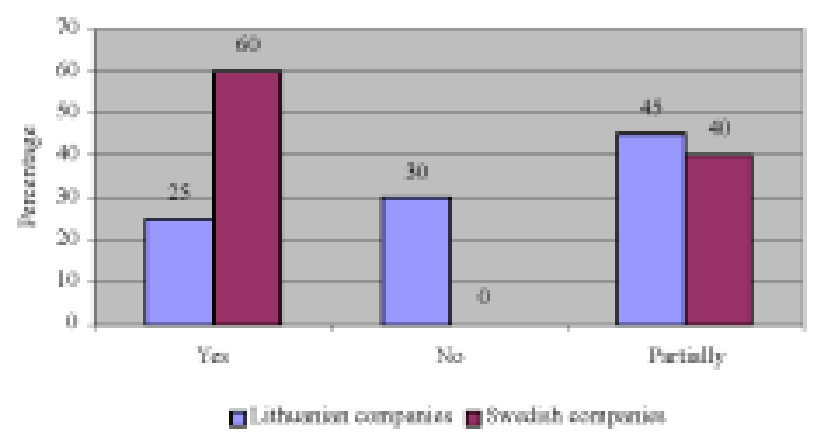

Fig 7. Is the information on advertising budget of construction companies confidential?

company, corresponding $20 \%$ of the re-spondents, intend to increase the expenses on advertising.

Fig 7 reveals that even $30 \%$ of the Lithuanian construction companies makes information about their advertising budget available to all, $45 \%$ of companies responded that such information is partially confidential and only $25 \%$ of companies considers this information confidential. It was also noticed that larger construction organisations are bound to keep information about advertising budgets in confidence in order to protect the immunity of their company. The results displayed in the figure indicate that the information about advertising budgets of three largest Swedish construction companies is confidential and the information about advertising budgets of two smaller ones is partially confidential.

Figs 8 and 9 provide details about the share of annual advertising budget of construction companies by different media and that the biggest share of funds is made by printed advertisements (average $46 \%$ in the Lithuanian and $43 \%$ in the Swedish companies) and public advertisements (average $17 \%$ in the Lithuanian and $21 \%$ in the Swedish companies), and these figures are expected to climb in the future.

Fig 8 reveals that the Lithuanian construction companies allocate advertising funds in the following way: $11 \%$ to special advertising, $8 \%$ to direct advertising, $8 \%$ to demonstrative advertising, $7 \%$ to in-store advertisements and

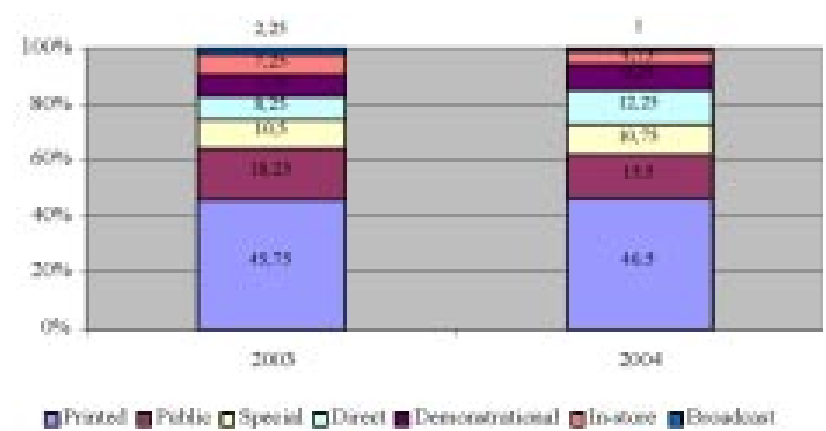

Fig 8. Share of annual advertising budget of the Lithuanian construction companies by different media

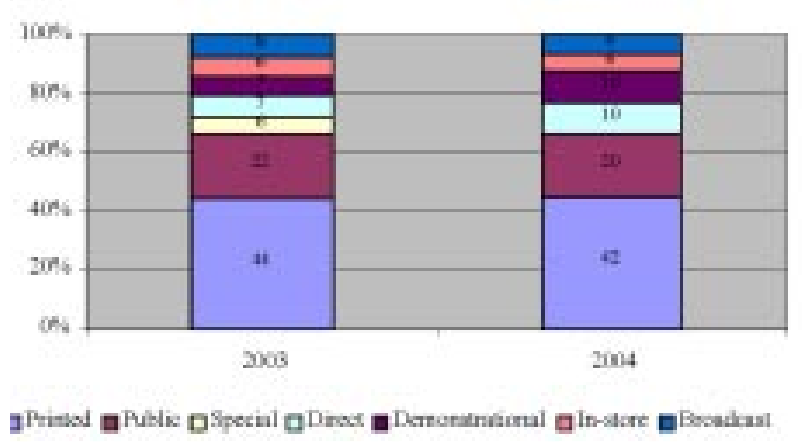

Fig 9. Share of annual advertising budget of the Swedish construction companies by different media

only $2 \%$ to broadcasting. Similar indicators are among the Swedish construction companies. It was also noticed that the Lithuanian and Swedish companies intend to reduce expenses for broadcastings and in-store advertisements, and increase expenses for direct and demonstrative advertising in the future. Thus, direct and demonstrative advertising is among the newest and most modern means of advertising and its popularity increases.

As the results of the survey indicate that almost $100 \%$ of the Lithuanian construction companies uses certain types of printed advertising media, about $75 \%$ of the companies uses public advertising, $70 \%$ uses direct advertising, about $60 \%$ of the companies uses special advertising media, $45 \%$ of the companies advertises itself in-store, $35 \%$ uses demonstrative advertising, and only about $15 \%$ of the companies uses broadcast advertising.

The results displayed in Fig 10 indicate that construction companies invest in periodicals, among printed advertising media, most. Periodicals get about $65 \%$ of funds for printed advertising in Lithuania, and $81 \%$ in Sweden. The second place goes to public advertising. Figs 8 and 9 show that the Lithuanian companies allocate up to $18 \%$ of their annual advertising budget to public advertising, and Swedish companies allocate up to $22 \%$.

According to the Lithuanian media survey company TNS Gallup [1], media advertising market rose $27.9 \%$ (including the Internet and cinema advertising market) in 2004. 


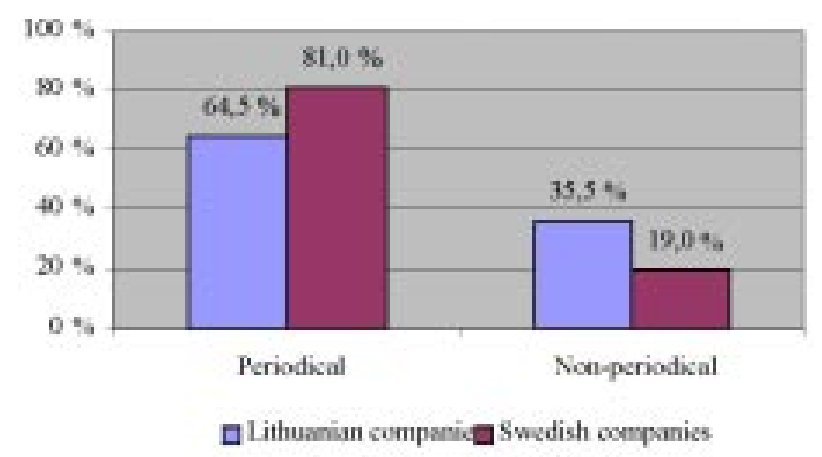

Fig 10. Allocation of funds for printed advertisement in construction companies

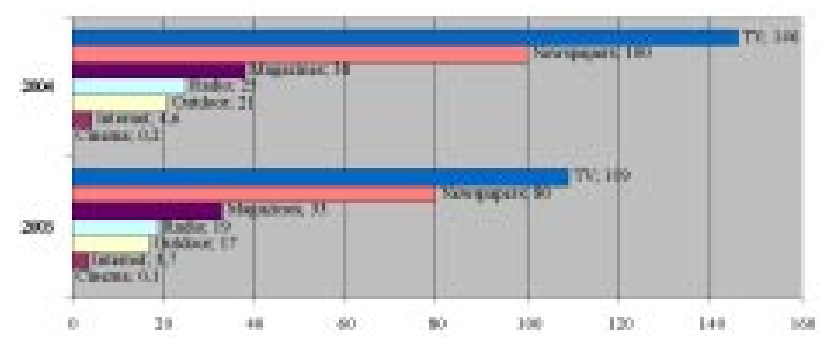

Fig 11. Real advertising income of media channels in Lithuania (in million of Litas) [1]

The total advertising expenditure in Lithuania accounted for 334.88 million Litas in 2004 including the volume of media channels and other discounts. According to media channels the biggest share of income fell on TV $-43.6 \%$ and newspapers - $29.9 \%$. Compared with 2003 expenditure on advertising in TV surged $33.9 \%$, newspapers $-25 \%$, magazines $-15.2 \%$, radio $-31.6 \%$ in 2004 . Outdoor advertising market (also considering the volume of outdoor video advertising) grew $23.5 \%$ in 2004 . The growth of the Internet advertising has worked out $24.3 \%$ (excluding the Internet advertising of catalogues) and cinema advertising market has sprouted twice. The results are displayed in Fig 11.

What is the situation in the construction sector? It must be stressed that many construction companies do not use broadcast advertising due to its high price. Therefore, companies select printed and public advertising media more often.

The use of the Internet rapidly increases every year. The number of users increased due to reduced prices of access and service quality increased due to higher speeds. In recent years the growth of the Internet use is noticed in the construction sector of Lithuania as well. Therefore, prices for advertisements in portals with construction information increase.

Fig 12 indicates that most Lithuanian construction companies select advertising media according to several criteria: $40 \%$ of companies selected advertising media considering their price and type of products or services, $35 \%$ con-

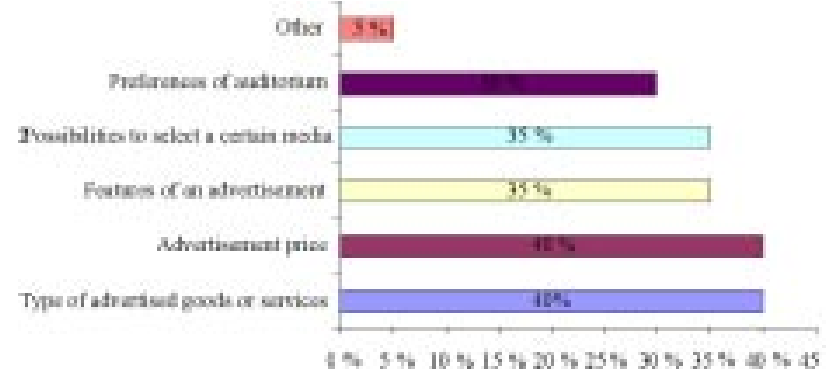

Fig 12. On what basis construction companies select advertising media

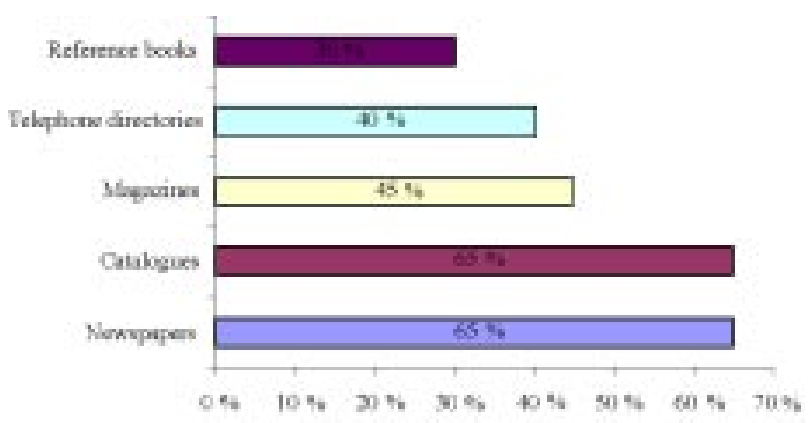

Fig 13. Advertising of the Lithuanian construction companies in periodicals

sidering the features of an advertisement and possibilities to select certain media and $30 \%$ considering the preferences of auditorium. One company pointed that it selects advertising media intuitively; and again it illustrates the attitude of some Lithuanian companies to advertising planning. The Swedish construction companies, however, thoroughly evaluate each type of advertising media before the selection.

The research results reflect the complexity and financial potential of the construction sector. As we can see, when construction companies plan their advertising, all reasons for the selection of advertising media are equally important and more or less influence the decision of a company. Considering these factors the company must select one or several media types, decide which will be the main and which supplementary, and allocate the planned advertising budget.

The variety and the number of printed advertising media are great. A company, considering its possibilities and aims of its advertising campaign, can easily select several of them. Fig 13 reveals that newspapers and directories are the most popular: even $65 \%$ of the Lithuanian construction companies selects them; and $45 \%$ of the companies places their advertisements in magazines which are mostly specialised magazines on construction, $40 \%$ of the companies places their information in telephone directories and $30 \%$ in reference books.

The research of non-periodical publications showed that $45 \%$ of the Lithuanian construction companies uses post- 


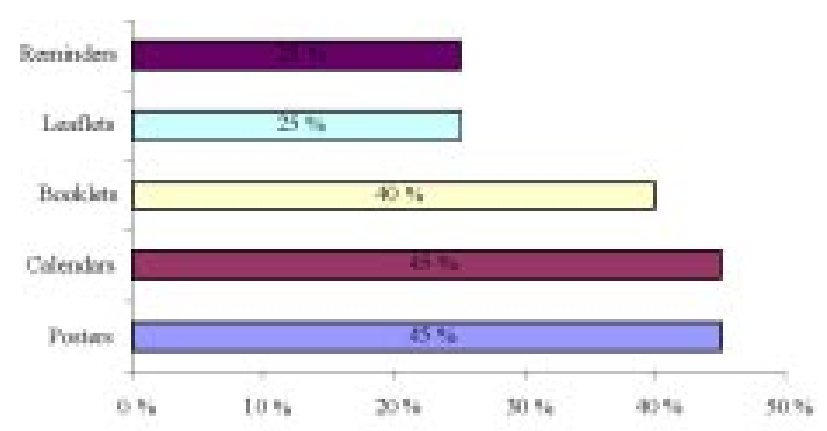

Fig 14. Advertising of the Lithuanian construction companies in non-periodicals

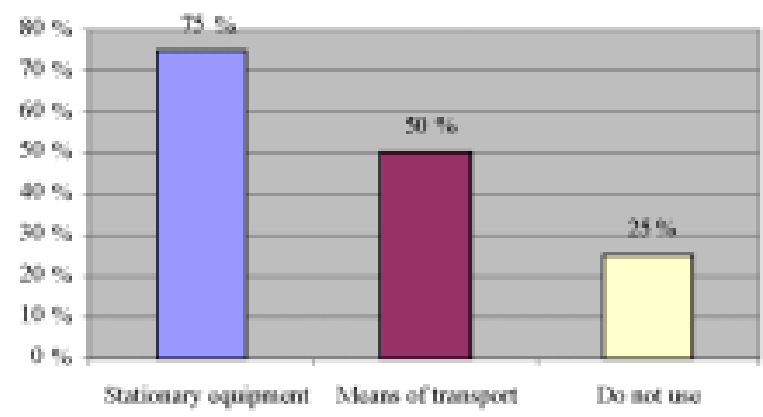

Fig 15. The percent of the Lithuanian construction companies which use public advertising

ers and calendars for their advertising, $40 \%$ issues own booklets and a quarter of companies distributes leaflets and reminders during their advertising campaign. The result is displayed in Fig 14.

The use of direct advertising is very important in advertising campaign of construction companies. Research results show that even $70 \%$ of the Lithuanian construction companies uses direct advertising: among them $55 \%$ sends advertisements using fax and computers and $25 \%$ uses post office services. Speaking about direct advertising means, most attention is paid to the computer or, to be more precise, to the distribution of advertisements via Internet. The Internet connection provides unlimited opportunities in the construction advertising; therefore its integration in the construction is among the most important tasks of a company.

Public advertising takes an important place in the construction. It has a number of advantages: low price, good access to auditorium, long-term effect and convenient publication. The technical facilities allow effective use of public advertising means in construction. As we know, special transport, walls, and fences surrounding construction sites are abundant in construction and advertisements placed on them are especially effective.

Fig 15 shows that even two thirds of the Lithuanian construction companies use means of public advertising: among them $75 \%$, corresponding 15 companies, uses stationary equipment and $50 \%$, corresponding 10 companies, places advertisements on the means of transport.

Based on the research, it may be claimed that the amount of public advertising should decrease in the Lithuanian and Swedish construction companies in the future. It was also determined that when the Lithuanian construction companies invest to public advertising, they spend most on stationary equipment $(75 \%)$, the remaining part (25\% correspondingly) is allocated to advertising on the means of transport. A similar situation is among the Swedish construction companies: $74 \%$ and $26 \%$ correspondingly.

As the results of the survey clearly indicate that all five Swedish companies which participated in the survey use a greater variety of advertising media for their advertising campaigns.

A construction company may plan its advertising in various ways: independently using services of advertising agencies and other companies involved in advertising business and combine both methods.

As we see, only a small part of construction companies in Lithuania uses services of advertising agencies for advertising planning. Companies try to use own efforts to the maximum and to save funds. However, the results of the research show that $80 \%$ of the Swedish companies uses all variants of advertising planning effectively.

Each advertising campaign is a certain investment for the company which organizes it. Therefore, the organizer is interested whether the aims of the campaign were achieved and whether they were effective. Thus, many companies foresee the control of the effect of advertising in the plan of their advertising campaign.

The research shows that about $90 \%$ of the Lithuanian construction companies tries to evaluate the effectiveness of advertising in one way or another. A half of the companies evaluates the effectiveness of their advertising campaign according to its economic effect, i.e. how the advertising contributed to the growth of profit of the company. A quarter of the companies analyses the communication effect using a direct evaluation method. Only $5 \%$ of the companies analyses the communication effect using a memory test. $20 \%$ of the respondents answered that they use their own methods to determine the advertising effectiveness. The

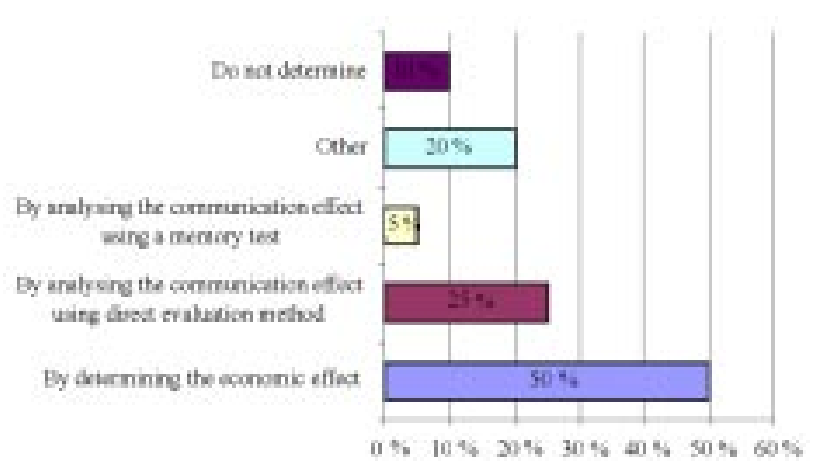

Fig 16. Methods used to determine the effectiveness of advertising campaign in the Lithuanian construction companies 
results are displayed in Fig 16.

Summarising the results of the research of the Swedish construction companies it may be claimed that they use a greater variety and a number of methods to determine the effectiveness of a company's advertising campaign. It was noted that the largest construction organisations evaluate the effect of advertising using several methods. This fact stresses exceptional aims and potential of these companies.

There are many reasons why the Lithuanian construction companies cannot have an exhaustive advertising campaign. Fig 17 reveals that advertising campaigns of $45 \%$ of companies usually are stuck due to the lack of corresponding funds, the same part of companies consider that prices of advertising are too high. About one fifth of companies complains about the lack of qualified personnel and organisational disadvantages of the company related to the lack. $15 \%$ of companies lacks information about the market, about $10 \%$ fears too great economic risks and $5 \%$ of companies lacks information about technologies. These are only some of difficulties encountered by companies in reality.

The survey of the Swedish construction companies shows that companies most often react to the lack of corresponding funds and high prices of advertising, and the lack of information about the market has an especially negative effect on advertising campaigns. We could guess that it is closely related to the activities of companies abroad.

As we see, financial resources have the greatest influence on the advertising in construction. The lack of funds is a serious reason why construction remains among the industries with the lowest level of advertising.

As the results of the survey indicate that the obstacles for advertising campaign of the Lithuanian construction companies are financial shortages and too high advertising prices (as stated by $45 \%$ of the respondents), therefore construction companies are forced to apply cheaper and less effective advertising means (the biggest obstacles for publicity campaign of the Swedish construction companies are shortage of information about the market). Both the Lithuanian and the Swedish construction companies spend the biggest part of advertising funds on printed advertise-

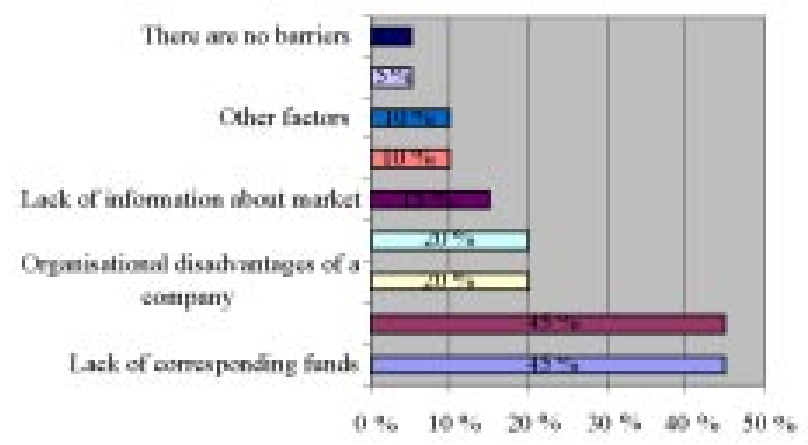

Fig 17. What factors cumber advertising activities of construction companies? ments (about $45 \%$ of the respondents). The larger half of these funds is budgeted for periodicals (in Lithuania $-65 \%$ ). According to the proportion of expenses in the advertising field the second place goes to public advertising.

Fig 18 provides that $60 \%$ of the Lithuanian construction companies surveyed organized advertising by their own strength. Not enough power is allocated to the organisation of advertising in construction companies. Investigating the employees working in the field of advertising in construction companies, it came out that only one full-time member of staff holds this position in the Lithuanian companies on the average. Usually this employee performs also other marketing functions, therefore, the qualitative performance of this work is practically impossible.

During the investigation, it has been determined that approximately $90 \%$ of Lithuanian construction companies tries to calculate the effectiveness of public campaigns. The effectiveness of a company's advertising campaign depends upon the personnel of the company in most cases. The results displayed in Fig 19 indicate that even $70 \%$ of Lithuanian construction companies relates to the experience of their employees planning advertising, about $35 \%$ of the companies uses special literature to get knowledge, $20 \%$ uses press, $15 \%$ uses Internet and about $10 \%$ of the companies sends their employees to special programmes or courses on advertising planning. The results show that the

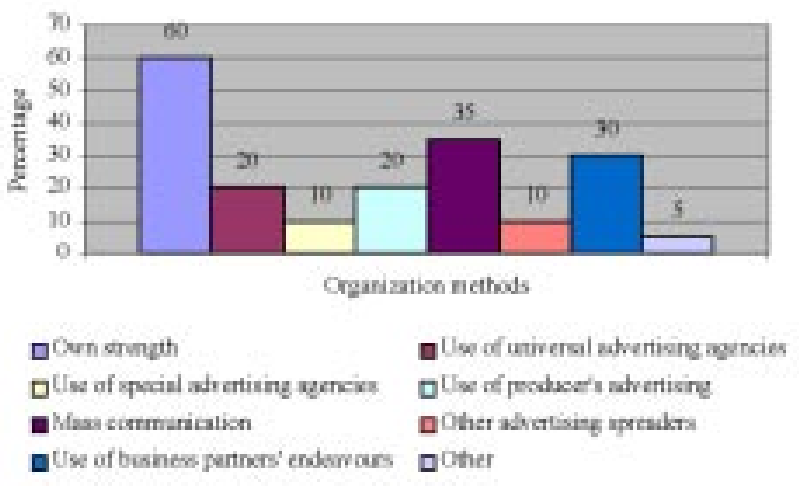

Fig 18. Methods used by the Lithuanian construction companies for advertising organization

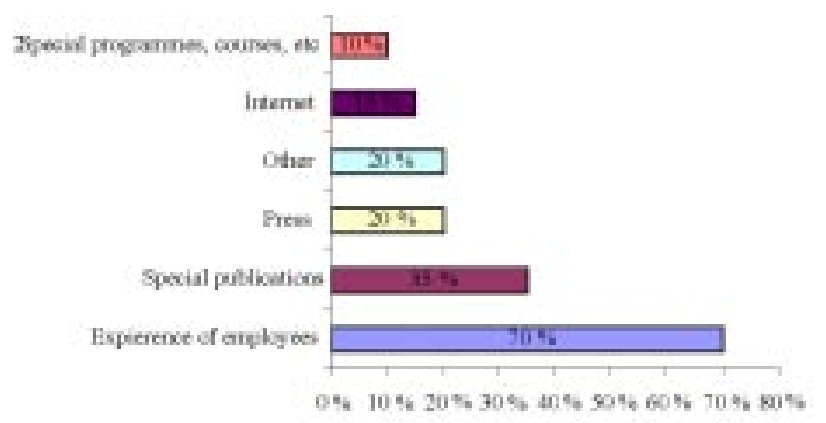

Fig 19. Sources of information about advertising planning used by employees of the Lithuanian construction companies 
Swedish construction companies pointed similar sources of information about advertising planning.

Respondents were asked, whether a construction company sufficiently observes its potential competitors. Referring to Fig 20, $45 \%$ of the Lithuanian construction companies, for one or another purpose, pays sufficient attention to activities of their competitors, $40 \%$ of companies responded that they observed competitors not very attentively by and $15 \%$ of the companies thinks that such practise is non-expedient.

The results of the Swedish construction companies show that even four companies out of five, corresponding $80 \%$ of the respondents, observe their competitors quite sufficiently and one is not very attentive. The results are displayed in Fig 20.

Fig 21 shows how Lithuania contributes to the support of stimulation of advertising planning in the construction sector. Referring to Fig 21, even $45 \%$ of the Lithuanian construction companies does not have information about such support, another $45 \%$ of the respondents claims that it never used such support, and only $10 \%$ of companies claims that they receive state support for advertising planning. Later it became clear that the latter was state-owned companies which use state subsidies. It must be acknowledged that Lithuania very rarely organises state-supported nation-wide or international exhibitions and competitions related to

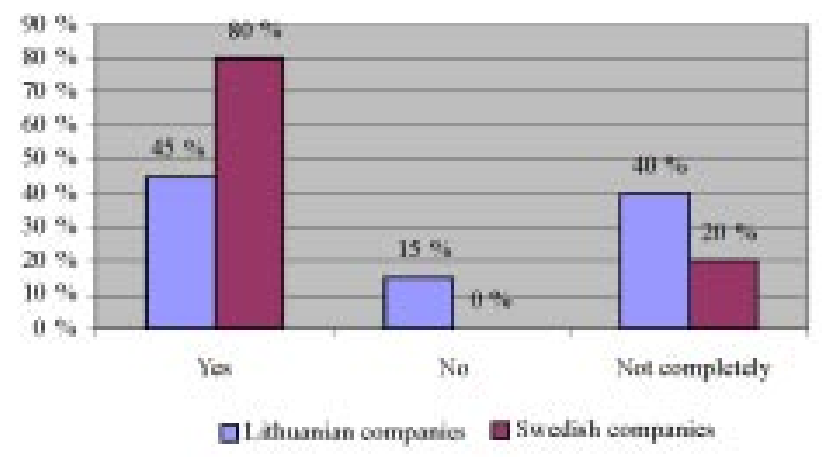

Fig 20. Whether construction companies sufficiently observe their potential competitors

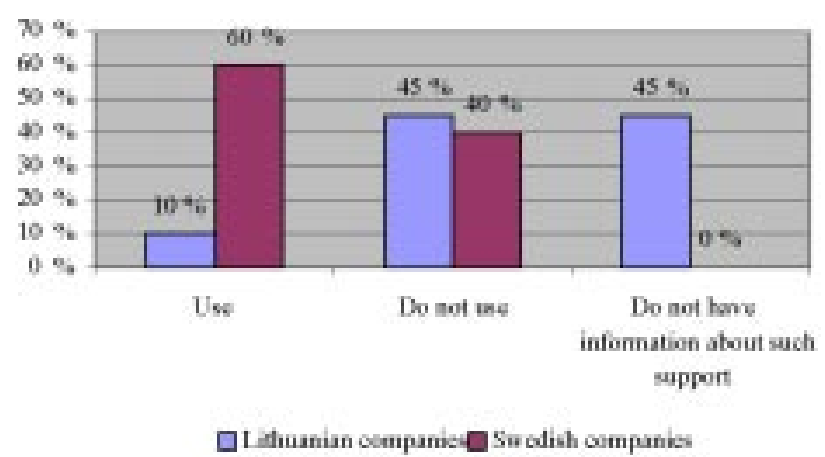

Fig 21. The percent of construction companies which uses state support for advertising planning

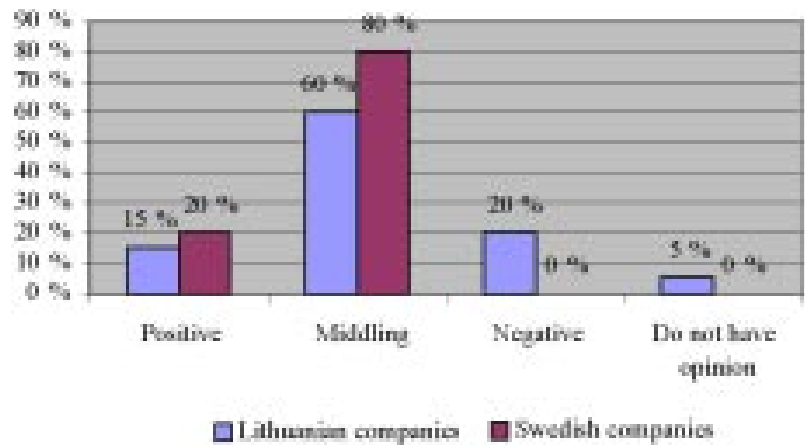

Fig 22. How respondents evaluate advertising campaigns of their national construction companies

construction in which construction companies of the country could promote not only their products and services, but also the name of Lithuania.

The survey of the Swedish construction companies showed that even three companies out of five use state support for advertising planning.

Respondents were asked, how they evaluate the effectiveness of their company's advertising campaign. In tenpoint system, the Lithuanian construction companies evaluate the effectiveness of their advertising critically, i.e. they give 6.05 points. The Swedish companies evaluate their advertising campaigns better, i.e. by 8.2 points.

Fig 22 provides the evaluations of advertising campaigns of their national construction companies set by all respondents of the survey. The results show that $80 \%$ of Swedish companies gives average evaluation to advertising activities of their national construction companies, and $20 \%$ gives positive evaluation. In Lithuania, advertising activities of national construction companies are optimistically evaluated only by $15 \%$ of respondents, $5 \%$ of companies has no opinion, $60 \%$ of companies gives average evaluation and even one fifth of companies evaluates advertising activities critically.

The survey showed that only about $35 \%$ of the Lithuanian construction companies advertises abroad in one way or another. The Lithuanian construction companies most often advertise themselves in Germany, Belarus, Estonia, Latvia, Poland, Russia, Ukraine and Norway, i.e. neighbour countries are the most popular.

The Swedish construction companies advertise themselves abroad more often. The research shows that even four fifths of such companies do not limit themselves to advertising in their country. The Swedish companies are also bound to strengthen their activities in neighbour countries.

We should hope that in the future the Lithuanian economy will become stronger and positive changes will take place in the construction sector as well; the Lithuanian construction companies will get additional funds and motivation to increase the amounts of advertisements not only in our country, but also abroad. 


\section{Conclusions}

Based on the findings of this research, the following conclusions can be drawn:

- Many Lithuanian construction companies are substantially oriented to direct sales, while too little attention is paid to advertising.

- In the Lithuanian construction companies there is a shortage of experienced advertising specialists; therefore the companies are forced to learn not from the others, but from their own mistakes.

- The investigation has shown that one fifth of the Lithuanian construction companies participating in the survey complains about the lack of qualified personnel and the organisational problems related to it. It has also been determined that even $60 \%$ of construction companies organises advertising with their efforts. Not enough power is allocated to the organisation of advertising in construction companies; therefore, the qualitative performance of this work is practically impossible.

- Even $50 \%$ of construction companies does not apply any methods for planning of advertising budget, does not afford sufficient observation of their competitors. They master the new technologies very heavily, passively participate in local and international exhibitions and fairs, advertise abroad too little and too constricted. Planning the annual advertising budget the Lithuanian construction companies usually apply the affordable method. During the investigation it has been noticed that the Swedish companies usually apply percentage-of-sales method for planning their advertising budget. Calculating the financial resources allocated to advertising it has been determined that large construction companies having big annual turnover spend more money on advertising, however, the sum expressed in percent is many times less than the one of the other companies.

- For the selection of advertising means printed advertising in the Lithuanian construction companies is the most popular. Almost all construction companies in the country applies these advertising tools. About $75 \%$ of companies applies public advertising means, $70 \%$ - direct advertising (only one third of the Lithuanian construction companies applies the Internet for the organisation of advertising), about $60 \%$ of companies uses special advertising media, $45 \%$ advertises in-store, $35 \%$ uses demonstrative advertising and only $15 \%$ profits from using broadcast advertising means. This is one of the more substantial advertising features of construction companies, as in general broadcast advertising means lead according to their popularity in nearly all industries.
Investigating the market of the Lithuanian construction companies, guidelines for better advertising in construction companies are suggested:

- For micro-enterprises and small construction companies to find good, energetic, open to information, perspective marketing specialists that would coordinate satisfaction of consumer needs and actions of competitors. Applying effective advertising means systematically, it is essential to form a beneficent image of a company and to increase the extent of construction.

- For medium-sized and large construction companies to cooperate more often with the professional advertising agencies, to establish functional subdivision of marketing in a company that would prepare marketing strategy, systematize information, perform market research and apply more effective promotion means and to support company seeking its goals.

\section{References}

1. Lithuanian advertising market grew rapidly last year (Press release). Retrieved October 1, 2005 from the World Wide Web: http://www.tns-gallup.lt/en/disp.php/en_news/en_news_79.

2. Kotler, P.; Armstrong, G. Marketing: an introduction. Englewood Cliffs: Prentice Hall, 1993. 632 p.

3. Kotler, P.; Armstrong, G.; Saunders, J.; Wong V. Principles of marketing. Harlow: Pearson Education, 2001. 856 p.

4. Morden, A. R. Elements of marketing. London: DP Publications, $1996.435 \mathrm{p}$.

5. Ginevičius, R.; Auškalnyte, R. The evaluation of a company's strategy by the Ansoff's product market matrix. Statyba (Civil Engineering), Vol 7, No 2. Vilnius: Technika, 2001, p. 158165 (in Lithuanian).

6. Ginevičius, R.; Korsakienè, R. The influence of marketing on business: theoretical and practical aspects. Business: theory and practice (Verslas: teorija ir praktika), Vol 5, No 3. Vilnius: Technika, 2004, p. 109-115 (in Lithuanian).

7. Mochtar, K.; Arditi, D. Pricing strategy in the US construction industry. Construction Management and Economics, Vol 19, Issue 4, 2001, p. 405-415.

8. Cicmil, S.; Nicholson, A. The role of the marketing function in operations of a construction enterprise: misconceptions and paradigms. Management Decisions, Vol 36, Issue 2, 1998, p. $96-101$.

9. Arens, W. F. Contemporary advertising. Boston: McGraw-Hill Irwin, 2002. $704 \mathrm{p}$.

10. Lombard, M.; Snyder-Duch, J. Interactive advertising and presence: a framework. Journal of Interactive Advertising, Vol 1, No 2, 2001. Retrieved July 1, 2005 from the World Wide Web: http://www.jiad.org/vol1/no2/lombard/index.html.

11. Pabedinskaitè, A.; Rojutè-Gaukšienè, J. Internet advertising campaign. Business: theory and practice (Verslas: teorija ir praktika), Vol 5, No 3. Vilnius: Technika, 2004, p. 90-99 (in Lithuanian).

12. Dijkstra, M.; Buijtels, H. E. J. J. M.; van Raaij, W. F. Separate 
and joint effects of medium type on consumer responses: a comparison of television, print, and the Internet. Journal of Business Research, Vol 58, Issue 3, 2005, p. 377-386.

13. Karson, E. J.; Korgaonkar, P. K. An experimental investigation of internet advertising and the elaboration likelihood model. Journal of Current Issues \& Research in Advertising, Vol 23, Issue 2, 2001, p. 53-72.

14. Lei, R. M. An assessment of the World Wide Web as an advertising medium. The Social Science Journal, Vol 37, Issue 3, 2000, p. 465-471.

15. Bezjian-Avery, A.; Calder, B.; Iacobucci, D. New media advertising vs. traditional advertising. Journal of Advertising Research, Vol 38, Issue 4, 1998, p. 23-32.

16. Chang, Y.; Thorson, E. Television and web advertising synergies. Journal of Advertising, Vol 33, Issue 2, 2004, p. 75-84.

17. Moorthy, S.; Hawkins, S. A. Advertising repetition and quality perception. Journal of Business Research, Vol 58, Issue 3, 2005, p. 354-360.

18. Lambertini, L. Advertising in a dynamic spatial monopoly. European Journal of Operational Research, Vol 166, Issue 2, 2005, p. 547-556.

19. Jefkins, F. Advertising. London: M+A, 1994. 374 p.

20. Dalrymple, D. J.; Parsons, L. J. Basic marketing management. New York: John Wiley \& Sons, 1995. 457 p.

21. Kwak, N. K.; Lee, C. W.; Kim, J. H. An MCDM model for media selection in the dual consumers/industrial market. European Journal of Operational Research, Vol 166, Issue 1, 2005, p. 255-265.

22. Ackerberg, D. A. Advertising, learning, and consumer choice in experience good markets: an empirical examination. International Economic Review, Vol 44, No 3, 2003, p. 1007-1040.

23. Morrill, J. E. Industrial advertising pays off. Harvard Business Review, Vol 48, Issue 2, 1970, p. 4-14, 159-169.

24. Hadad, Y.; Fiedman, L; Israeli, A. A. Evaluating hotel advertisements efficiency using data envelopment analysis. Journal of Business Economics and Management, Vol V, No 3. 2004, p. 133-141.

25. Hiam, A.; Schewe, C. D. The portable MBA in marketing John Wiley \& Sons Inc, 1992. 464 p.

26. Kotler, P. Marketing management. Upper Saddle River: Prentice Hall, 2000. 751 p.

27. Herrbach, O.; Mignonac, K. How organisational image affects employee attitudes. Human Resource Management Journal, Vol 14, Issue 4, 2004, p. 76-88.

28. Si, S. X.; Hitt, M. A. A study of organizational image resulting from international joint ventures in transitional economies. Journal of Business Research, Vol 57, Issue 12, 2004, p. 1370 1377.

29. Bovee, C. L.; Thill, J. V. Marketing. New York: McGraw-Hill, 1992. $761 \mathrm{p}$.

30. Armstrong, G. M.; Franke, G. R.; Russ, F. A. The effects of corrective advertising on company image. Journal of Advertising, Vol 11, Issue 4, 1982, p. 39-45, 76.

31. Sūdžius, V. Means of creation enterprise reputation and image. Business: theory and practice (Verslas: teorija ir praktika), Vol 2, No 1. Vilnius: Technika, 2002, p. 59-65 (in Lithuanian).

32. Palazon-Vidal, M.; Delgado-Ballester, E. Sales promotions effects on consumer-based brand equity. International Journal of Market Research, Vol 47, Issue 2, 2005, p. 179-204.

\section{REKLAMOS STATYBOJE TYRIMAS: LIETUVOS IR ŠVEDIJOS İONIŲ PATIRTIES ANALIZE்}

\section{A. Banaitis, N. Banaitienè}

Santrauka

Statyba, kaip marketingo objektas, turi tam tikrų ypatybių: statybos aplinka yra kompleksinè ir kintama, klientų reikalavimai ir lūkesčiai nuolat auga. Statybos įmonès turi suprasti, kad geras marketingas ir ypač reklama turi didelę ịtaką statybos produktų ir paslaugų pardavimams, o tai ypač svarbu šiandieninès rinkos sąlygomis. Straipsnyje pateikiamas Lietuvos ir Švedijos statybos įmonių kokybinis tyrimas, kuriame nagrinėjami reklamos kampanijos, biudžeto ir nešikliu klausimai. Nagrinėjami ir reklamos efektyvumo ivvertinimo klausimai. Tyrimas parodè, kad daugelis Lietuvos statybos įmonių reklamuojasi savo jègomis. Kadangi ịmonių darbuotojai neturi reklamos organizavimo patirties ir žinių, jie dažnai priima netinkamus sprendimus. Lietuvos statybos įmonių tyrimas parodė, kad imonès neskiria pakankamai lèšu įmonès produktų ar paslaugų reklamai, ir reklamos biudžetas yra glaudžiai susijęs su pasirinktais reklamos nešikliais. Straipsnio pabaigoje aptariami tyrimo rezultatai ir pateikiami siūlymai statybos įmonių reklamai organizuoti.

Raktažodžiai: reklama, statybos įmonè, reklamos nešikliai, reklamos kampanija, tyrimas.

Audrius BANAITIS. Associate Professor in the Department of Construction Economics and Property Management at Vilnius Gediminas Technical University. His research interests include building economics and policy, housing finance, sustainability and housing development, management of construction, innovation management, multiple criteria decision making: applications in construction.

Nerija BANAITIENE். Associate Professor in the Department of Construction Economics and Property Management at Vilnius Gediminas Technical University. Her research interests include project management, total quality management, building life cycle analysis, multiple criteria decision making: applications in construction. 